William Davies, The Limits of Neoliberalism: Authority, Sovereignty and the Logic of Competition (revised edition)

London: SAGE, 2017, 248 pp

\title{
Neoliberal Reason and the Displacement of Politics
}

SEAN PHELAN

The last decade has seen the publication of many excellent books about neoliberalism that have challenged some of the glib stereotypes that attach themselves to the term. One of the most acclaimed has been William Davies's 2014 book The Limits of Neoliberalism, and justifiably so. The book has already been published in revised edition in 2017, with a new preface reassessing the argument in light of the Euro-American political dislocations of 2016. A co-director of the Political Economy Research Centre at Goldsmiths, University of London, Davies has been a prolific author since the publication of the 2014 edition, publishing two more books that have given him a readership well beyond the academy, and becoming a regular contributor to publications like The Guardian, London Review of Books, and The New York Times. The praise for The Limits of Neoliberalism has been near universal. The writer and journalist Paul Mason cited it in 2018 as one of the five books that best explain the condition of the Left today. According to Mason, it sums up the way in which the 'modern left' has come to think about neoliberalism, particularly the reinvigorated Left programme of the UK 
Labour party under Jeremy Corbyn. ${ }^{1}$

Davies's book is certainly replete with insights that resonate with Left analyses of neoliberalism. But one of its most striking features is how it breaks from a Left reflex that simply critiques neoliberalism, or, more reductively, approaches it as an ideology to be disparaged and censured. Davies reflects on this point in the introductory chapter. He expresses admiration for critical theoretical and sociological research that highlights the deeper structural underpinnings of neoliberal capitalism, but voices a concern that the normative and political force of such work-its 'rush to explain or to criticize' - can obscure our interpretive understanding of neoliberalism as an object of analysis. ${ }^{2}$ Davies's reservations about a onedimensional critique of neoliberalism are well-founded, not only because of the existence of a genre of Left analysis and commentary that rarely gets beyond denunciatory mode. It also invites us to think about how the gesture of critiquing the thing called 'neoliberalism' can become a banal rhetorical act, sufficiently nebulous in its political commitments that it is open to being affirmed by people that others might see as proponents of neoliberal order.

Recall, for instance, the moment during the 2017 General Election campaign when Radio New Zealand's Guyon Espiner asked Jacinda Ardern whether neoliberalism had failed. Ardern answered with a seemingly unequivocal 'yes', but her answers to Espiner's follow-up question, 'so what elements and aspects of the neoliberal agenda would you roll back?', were far more uncertain and tentative. ${ }^{3}$ Espiner's initial question cited an interview he did with former Prime Minister Jim Bolger earlier in 2017, where, unprompted, Bolger suggested that 'neoliberal economic policies

1 Paul Mason, 'Five books to understand the left,' The Guardian, 19 February 2018, https:/www.theguardian.com/books/2018/feb/19/paul-mason-five-books-tounderstand-the-left

2 William Davies, The Limits of Neoliberalism: Authority, Sovereignty and the Logic of Competition (London: SAGE, 2017), 11.

3 Guyon Espiner, 'The Leader Interview - Jacinda Ardern,' Radio New Zealand, 12 September 2017, https:/www.radionz.co.nz/news/political/339209/the-leaderinterview-jacinda-ardern 
[had] failed'. ${ }^{4}$ However, when Espiner suggested that Bolger had 'embarked on that model' himself, Bolger immediately distanced neoliberalism from the 'pragmatic policies' of his own government.

Both disavowals of neoliberalism are revealing: they position it as the name for a rigid and monolithic ideological identity that is opposed to Ardern and Bolger's shared self-image of themselves as policy pragmatists. To invoke a concept often cited in the literature on neoliberalism, both obscure their own entanglement in an ideologically protean world of 'actually existing neoliberalism', because of their internalisation of the erroneous assumption that, if it is to exist at all, neoliberalism must be expressed in some 'pure', doctrinal form. ${ }^{5}$ Davies is a useful guide in this respect, as he is alert to both the different articulations of neoliberal reason and its embodiment in social rituals and practices that assume the register of pragmatic policy commitments. In contrast to approaches that might interpret neoliberal justifications as offering little more than ideological camouflage, his book assumes that 'the performative and critical power of neoliberal discourse needs to be taken seriously, as a basis on which cryptopolitical and collective action does ... take place'. ${ }^{6}$

Davies defines neoliberalism as the 'pursuit of the disenchantment of politics by economics'? The definition brilliantly captures how neoliberal identification with economic and market measures of value has always been animated by an ideological antipathy to the logic of politics, despite the fact, of course, that the institutionalisation of this vision needed to become a political project in its own right. In the preface to the revised edition, Davies contrasts this pithy definition with a more 'cumbersome' one in which neoliberalism is defined as 'the elevation of market-based principles

4 Guyon Espiner, 'The Negotiator - Jim Bolger,' Radio New Zealand, 21 April 2017, https:/www.radionz.co.nz/programmes/the-9th-floor/story/201840999/thenegotiator-jim-bolger

5 Jamie Peck, Neil Brenner, and Nik Theodore, 'Actually Existing Neoliberalism,' in The Sage Handbook of Neoliberalism, ed. Damian Cahill, Melinda Cooper, and Martijn Konings (London: SAGE, 2018).

6 The Limits of Neoliberalism, 12.

7 The Limits of Neoliberalism, 6 
and techniques of evaluation to the level of state-endorsed norms' ${ }^{8}$ This second definition is equally elegant in its rebuttal of hand-me-down notions that define neoliberalism through some rigid opposition between state and market. This dichotomy has never been a very helpful way of understanding the nature of neoliberal regimes, though it is often assumed in shorthand descriptions of neoliberalism as code for 'free market' and 'laissez faire' ideology. For instance, in her extended answer to Espiner's question about whether neoliberalism had failed, Ardern sought to distance herself from the term; she insisted 'that New Zealand has been served well by interventionist governments', contrasting her belief in a 'more interventionist' philosophy with an implicitly neoliberal one that 'would allow the market to just dictate outcomes for people'?

To be fair, it is not surprising that the idea of state intervention in the economy is still construed as signifying opposition to neoliberalism in Aotearoa New Zealand, such was the intensity of the market fundamentalist assault on the social democratic state during the Rogernomics and Ruthanasia years. ${ }^{10}$ At the same time, though, banal rhetorical distinctions between state and market, intervention and non-intervention, hamper our ability to grasp the character of neoliberalism, and can cultivate the selfserving impression among politicians - particularly in the Labour partythat any statutory intervention in the economy constitutes a departure from some strict orthodoxy. As Foucault could already see in the 1970s, neoliberalism embodies an 'intervening liberalism' concerned with the project of reconstituting the state and its citizens as agents and objects of market calculation. ${ }^{11}$

While Foucault is one of many theoretical sources cited in the book, Davies's approach is primarily informed by the so-called 'convention theory' and 'pragmatic sociology' tradition developed by the French

8 The Limits of Neoliberalism, xiv

9 Espiner, 'The Leader Interview - Jacinda Ardern'.

10 Brian Easton, The Commercialisation of New Zealand (Auckland: Auckland University Press, 1997).

11 Michel Foucault, The Birth of Biopolitics: Lectures at the College de France, 1978-1979 (Basingstoke: Palgrave Macmillan, 2008), 133. 
sociologist Luc Boltanski. As Davies summarises it, 'the task of convention theory is to identify and illuminate the normative, technical and critical resources that are employed' in the maintenance and justification of social order. ${ }^{12}$ This means critically excavating the social conventions and shared understandings that animate neoliberal policy regimes, interpretatively working through their 'ways of thinking, measuring, evaluating, criticizing, judging and knowing'. ${ }^{13}$ It also means being alert to the performative contradictions that are generated when those conventions start to lose their normative force, and the limits of neoliberal authority become more publicly visible.

Davies suggests 'neoliberalism's greatest dilemma' concerns its relationship with 'political sovereignty, in the sense of an ultimate source of political power or authority'. ${ }^{14}$ On the one hand, neoliberals are motivated by a desire 'to replace politics with economics', substituting the perceived arbitrariness and normativity of political judgements with regimes of 'objective' scientific measurement. On the other hand, neoliberals cannot escape the inherently political underpinnings of their project and 'their wish to place sovereignty on economically rational foundations'. ${ }^{15}$ Davies argues that the desire to install techniques of economic measurement as a foundational basis of social order is ultimately impossible, because 'the discourse and techniques of economics are not self-justifying'; they always 'depend on silent, unseen sources of obligation, be they tacitly understood as norms of cooperation or tacitly understood as sources of political power'. ${ }^{16}$ Davies isn't a rhetorical theorist; however, his sensitivity to the rhetorical character of neoliberalism resonates with work highlighting how neoliberal identities are articulated through a 'market realist' and 'economically correct' rhetoric that crucially doesn't see itself as rhetorical. Within the neoliberal worldview, 'rhetoric' (much like ideology) is seen as the attribute

12 The Limits of Neoliberalism, 13.

13 The Limits of Neoliberalism, 14.

14 The Limits of Neoliberalism, 24.

15 The Limits of Neoliberalism, 25.

16 The Limits of Neoliberalism, 25. 
of the Other - the domain of those spouting metaphysical nonsense about politics. ${ }^{17}$ The neoliberal championing of economic measurement and empirical technique in opposition to politics and normativity are ultimately the basis of 'rhetorical' rather than 'ontological' distinctions, Davies argues, which obscure the value-laden character of any empirical description. ${ }^{18}$

One of the great strengths of Davies's book is its attention to the internal heterogeneity of neoliberal thought and the different articulations of market rationality within a broader liberal philosophy (readers inclined to see the distinction between liberalism and neoliberalism as tautologous may be less enamoured). He highlights what he sees as a key historical shift in the genealogy of neoliberalism, which saw a principled 'justification for markets' mutate into an open-ended 'justification for business' that privileged the interests of transnational corporations. ${ }^{19}$ For the ordoliberal regime established in (West) Germany after World War Two, the institutionalisation of a market-order was primarily a constitutional question, focused on establishing a universal set of legal rules that would enable a competitive dynamic between different market players that curbed monopolistic tendencies. This folksy image of an idealised marketplace, premised on some notion of an equal playing field, later morphed into the legitimation of a quite distinct doctrine of 'market competitiveness'. This was mediated by the ascendency of neoclassical and Chicago School economic theories that fretted less about the exact composition of markets, so long as the allocation of economic resources could be deemed more 'efficient' by the objective evaluations of an increasingly powerful class of economist-experts. Neoliberal reason became progressively embedded in a straightforward justification of capitalist power, exemplified for Davies in the figure of 'the heroic, creative entrepreneur' eulogised for their capacity to conquer and dominate market rivals. ${ }^{20}$ Instead of a 'formal-

17 James Arnt Aune, Selling the Free Market: The Rhetoric of Economic Correctness (New York: The Guilford Press, 2001); see also, Sean Phelan, Neoliberalism, Media and the Political (Basingstoke: Palgrave Macmillan, 2014).

18 The Limits of Neoliberalism, 17.

19 The Limits of Neoliberalism, 50.

20 The Limits of Neoliberalism, 51. 
structural emphasis on competition as an essential property of markets', 'competitiveness' was recast in psychological terms as an essential trait of individuals, opening the way for a now familiar world where the tools of 'neoliberal critique' and audit were deployed to highlight the competitive deficiencies of institutional practices beyond a strictly commercial domain. ${ }^{21}$

Chapter three focuses most explicitly on the Chicago School and documents the importance of the so-called 'law and economics movement' to the institutionalisation of neoliberal imperatives. ${ }^{22}$ The importance of law to the establishment of market order was already clearly grasped by the ordo-liberals in the 1940s. It was also a central concern of the work of the most important neoliberal theorist, Friedrich Hayek. But the interplay of economic and legal imperatives was given distinct ideological expression in a Chicago School doctrine that sought to colonise legal judgments with neoclassical economic assumptions and disparage any contrary 'metaphysical' arguments 'about what a market or economy "ought" to look like'. ${ }^{23}$ Aided by the emergence of a network of 'Chicago-influenced judges and economists in the courtroom, and by economists within anti-trust agencies themselves', this intellectual project was remarkably successful in overturning anti-trust laws in the US during the 1970s and 1980s. ${ }^{24}$ Its influence was also discernible in a pattern of competition law judgements by the New Zealand Commerce Commission that was similarly agnostic about monopolistic or duopolistic practices, so long as there were no formal barriers to the possibility of future competition. ${ }^{25}$ "The question of "just or unjust" was displaced by one of "efficient or inefficient", and economists' power to determine what constituted relevant evidence assumed a 'quasijudicial' status. ${ }^{26}$ The strategic 'intentions, practices and norms' of situated

21 The Limits of Neoliberalism, 21, 51.

22 The Limits of Neoliberalism, 87.

23 The Limits of Neoliberalism, 85.

24 The Limits of Neoliberalism, 96.

25 Nathan Strong, Alan Bollard, and Michael Pickford, 'Defining Market Dominance: A Study of Antitrust Decisions on Business Acquisitions in New Zealand,' Review of Industrial Organization 17, no. 2 (2000): 209-227.

26 The Limits of Neoliberalism, 76-77. 
market actors were ignored in favour of measured effects as calculated by economists'. ${ }^{27}$ In a world where the motivations of all other social actors were diagnosed and explained through the self-interested axioms of neoclassical economics and rational choice theory, economists assumed the authority of 'disinterested' and 'objective' experts with the analytical clarity to see through the spurious 'moral reasoning' and bullshit of others. ${ }^{28}$

Any assessment of neoliberalism in our current political moment means thinking about its relationship with nationalism. Taking his cue from David Harvey's observation that 'the neoliberal state needs nationalism of a certain sort to survive', Davies's examination of the discourse of national competitiveness in chapter four had not yet anticipated the recent reinvigoration of the far-right. ${ }^{29}$ But his analysis of the antagonistic dynamics between different nation-states competing on a global stage now reads as a prescient discussion of the emergence of a more aggressive form of 'neoliberal nationalism' 'in which rules are only recognised to the extent that they offer a strategic local advantage'. ${ }^{30}$ He argues that a tamed version of Carl Schmitt's stark existential conception of politics as a domain of 'friend-enemy' conflicts was institutionalised in a 'new type of political-economic contest'; this lay between some mythical liberal utopia where market competition benefits everyone and a 'zero sum geopolitical contestation between states' now visible in the 'America first' impulses of the Trump administration. ${ }^{31}$

Under the regime of 'neoliberal internationalism' described by Davies, the management of a nation-state's competitive standing vis-à-vis other nations has come to be regarded as the core function of government. ${ }^{32}$ The project of 'branding' the nation to render it more attractive to the

27 The Limits of Neoliberalism, 95.

28 The Limits of Neoliberalism, 101.

29 The Limits of Neoliberalism, 119.

30 Adam Harmes, 'The Rise of Neoliberal Nationalism,' Review of International Political Economy 19, no. 1 (2012): 59-86; The Limits of Neoliberalism, 157.

31 The Limits of Neoliberalism, 131-132.

32 Harmes, 'The Rise of Neoliberal Nationalism.' 
imperatives of global and domestic capital becomes part of an (anti-)political common-sense that dissolves distinctions between politics, business, and marketing, and invites ridicule of any political programme seen as threating the strategic objective of national competitiveness. Davies's discussion of how 'executive authority' was reinvented under neoliberalism will summon plenty of associations for New Zealand readers: the dull 'capitalist realism' of the Key years for starters, though we can also recall the heightened attention to cultural identity as a source of global market differentiation under the Labour-led governments of Helen Clark. ${ }^{33}$ Davies's analysis also invites reflection on how governmental authority was reconstituted in a variety of institutional settings, where the fixation with mimicking business practices and techniques changed the fundamental culture of different organisational domains.

Davies's argument about the performative limits and failures of neoliberalism crystallises in chapter five where he examines how neoliberal regimes responded to the 2007-2009 Global Financial Crisis (GFC). Davies argues that this widely narrated neoliberal crisis has spawned a regime of 'contingent neoliberalism'. This regime is in a literal sense unjustified, because it signifies a world where the authority of neoliberal reason can no longer convincingly claim to rest simply on technocratic and putatively apolitical commitments. ${ }^{34}$ The bailout of the banking system publicly dramatised the foundational paradox and amnesia at the heart of the neoliberal project: that 'its conditions of possibility' were dependent on the sovereignty of the state and a realm of 'political metaphysics' that neoliberals sought to replace with a purely economised conception of statehood. ${ }^{35}$ With the notion that economic methodologies might serve as a 'transcendental principle' of social order seemingly fatally damaged, neoliberal justifications have become zombie-like, appealing to 'forms of conduct' and 'representations of reality' increasingly denuded of public

33 The Limits of Neoliberalism, 117; Mark Fisher, Capitalist Realism (London: Zero Books, 2009).

34 The Limits of Neoliberalism, 189.

35 The Limits of Neoliberalism, 161. 
legitimacy. ${ }^{36}$ And yet, the aftermath of the GFC belied claims about the 'death' of neoliberalism and saw the emergence of new forms of state intervention that aimed to recuperate neoliberal order through appeals to austerity. In the preface to the revised edition, Davies suggests the political 'eruptions of $2016 \ldots$ represented the long-awaited politicisation and publicisation of a crisis that, until then, had been largely dealt with by the same cadre of experts whose errors had caused it in the first place'. ${ }^{37}$

Although written before Trump's election as president, the revised preface poses the question of whether neoliberalism is 'dead or alive' in light of political events such as Brexit that have challenged some of the core assumptions of the original book. ${ }^{38}$ If neoliberalism can be defined as the 'disenchantment of politics by economics', Davies suggests that Brexit symbolises 'the revenge of politics on economics'. ${ }^{39}$ Those campaigning in favour of the UK's ongoing membership in the EU thought that citing the authority of a gallery of economists, technocrats, elite politicians, and corporate leaders would be sufficient to ensure a winning vote. Instead, the referendum result captured a public mood increasingly sceptical of expertise, as (in)famously captured in Tory minister Michael Gove's assertion during a televised campaign debate that 'I think the people in this country have had enough of experts [from] organisations [with] acronyms saying that they know what is best and getting it consistently wrong. ${ }^{40}$

If our understanding of neoliberalism is necessarily tied to the epistemological and cultural authority of a regime of technocratic expertise, the turbulent politics of 2016 may well be taken as evidence that the zombie has finally been killed off, with even economists from the

36 The Limits of Neoliberalism, 155-156.

37 The Limits of Neoliberalism, xv.

38 The Limits of Neoliberalism, xviii.

39 The Limits of Neoliberalism, xiv.

40 Fraser Nelson, 'Michael Gove was (accidentally) right about experts,' The Spectator, 14 January 2017, https://www.spectator.co.uk/2017/01/michael-gove-wasaccidentally-right-about-experts/ 
International Monetary Fund now lining up to critique 'neoliberalism'. ${ }^{41}$ Yet, the matter is not as simple as that, and to think otherwise is to fall into the analytical trap of defining neoliberal reason in rigid mechanistic terms that obscure its capacity for very different kinds of political and ideological articulations. For instance, neither of the two major dislocatory political events of 2016 (the Brexit vote and Trump's election) constituted a blanket disavowal of neoliberalism, even if both entailed the rejection of particular neoliberal regimes. Nancy Fraser suggests Trump's election victory symbolised the defeat of 'progressive neoliberalism', an alliance of mainstream feminist, anti-racist, multicultural, and LGBTQ+ social movements on the one side and Wall Street, Silicon Valley, and Hollywood corporate interests on the other. ${ }^{42}$ Trump has ruled through a regime of 'hyperreactionary neoliberalism' which dramatises the potential affinities between neoliberal and far-right ideologies. If disenchantment with politics is a hallmark of neoliberal reason, Trump surely represents one of the most vivid expressions yet of an anti-political mood where 'not being a politician' becomes an electoral asset. The Brexit vote likewise signified a rejection of neoliberalism, at least if we accept Left representations of the EU as a quintessential neoliberal institution. However, the Brexiters' hyperglobalist vision of a post-EU UK, a UK liberated from what they depict as a crypto-socialist EU, hardly represents a departure from a neoliberal script. Highlighting these contradictions should not be construed as suggesting that neoliberalism is somehow the only concept we need to analyse everything signified by Trump and Brexit. However, it is to encourage pause before we once again declare its death.

And what of neoliberalism in contemporary Aotearoa New Zealand? Ardern's disavowal may summon clearer questions than answers, but her official rejection of neoliberalism amounts to a very predictable rhetorical gesture from someone who knows that identifying with neoliberalism is

41 Jonathan Ostry, Prakash Loungani, and Davide Furceri, 'Neoliberalism: Oversold?' Finance \& Development 53, no. 2 (2016): 38-41.

42 Nancy Fraser, 'From Progressive Neoliberalism to Trump-and Beyond,' American Affairs 1, no. 4 (2017). Available at https://americanaffairsjournal. org/2017/11/progressive-neoliberalism-trump-beyond/ 
not the wisest way to 'rebrand' the Labour Party. In that respect, Ardern is simply following the lead of her political mentor Helen Clark who straddled a similarly awkward line of rejecting some notionally pure neoliberalism while concurrently affirming a 'Third Way' vision that became a byword for further neoliberalisation. To its champions from afar Ardern's government now distinguishes itself on the global stage as the embodiment of a progressive centre in a political atmosphere where the centre no longer holds. But in the reinvigorated Left universe symbolised by Jeremy Corbyn and Bernie Sanders, 'centrist' has become a default pejorative for critiquing the limits and vacuity of a liberal politics that continues to deny its own neoliberal underpinnings.

Whether Ardern's rhetorical commitments find a meaningful political footing can-if we are kind-be read as a still open question, though the evidence so far hardly amounts to much. The recent abandonment of the government's plans to introduce a capital gains tax symbolised an elite political culture still disenchanted with politics. Ardern's renunciation of the policy on the grounds that New Zealanders 'don't believe in it' exhibited her own affinities with the post-politics of John Key: public opinion is seen as a dull, static thing to be focus-grouped and polled, rather than something that needs to be politically made and animated beyond the back-stage machinations of the MMP system. ${ }^{43}$ Her government's strategy seemed to rest on a magical decoupling of policy prescription from the actual politics - as if the outsourced recommendations of the Tax Working Group would be enough to sway the argument and somehow forgo the need for rhetorical combat with the right-wing interests that set the terms of the public and media conversation in the days after the release of the working group's report.

I write at a time when the second budget of Ardern's government is four weeks away, so we can at least hope that there might be something on the horizon that belies the impression of post-political stasis. However, in

43 Peter Malcom, 'Dropping the capital gains tax lets selfishness and greed win,' Stuff, 18 April 2019, https://www.stuff.co.nz/business/opinion-analysis/112122449/ selfishness-and-greed-are-not-the-kiwi-way 
the spirit of Davies's book, perhaps we might be able to formulate a clearer diagnosis of the condition of neoliberalism in Aotearoa New Zealand today if we think less about the official ideological declarations of politicians and focus more on the condition of a public institution familiar to many of the readers of Counterfutures: the New Zealand university. In the most reactionary version of today's culture wars, the university is depicted as a hub of radical left-wing ideologues-'cultural Marxists' hell-bent on the indoctrination of students. This caricature is stupid for lots of reasons, but it is especially laughable as a description of an institutional universe where neoliberal determinations of efficiency seem, if anything, to be consolidating their authority among the managerial elite that run the corporate university. Evidence easily recorded and quantified on spreadsheetsenrolment numbers, research income, research audit scores, salary-student ratios, research outputs, global rankings, citation scores, contract hours, marking time, learning objectives, learning outcomes-have become the primary bureaucratic mediums for determining who or what is valued. Disenchantment with politics and normative questions finds expression in a managerial sensibility that has little time for the kinds of ideas and arguments circulating in the work of the 'clandestine university', unless they can be deployed to flatter the corporate brand. Academics (or at least many of us) submit to our own kind of 'there is no alternative' passivity, our grumbling largely confined to lunchtime snark and journal articles that critique neoliberalism. ${ }^{44}$ The possibility of a meaningful collective pushback feels remote, despite affirmative developments elsewhere; perhaps, we hope, a sign of things to come. ${ }^{45}$

Unless we challenge the forms of neoliberal reason that still hold practical authority in different institutional contexts in Aotearoa New Zealand and elsewhere-in our universities, in our public service, in our media system, and in our conception of (political) economy-ruminating

44 Thomas Docherty, 'Unseen Academy' Times Higher Education, 10 November 2011, http://www.timeshighereducation.co.uk/story.asp? storycode $=418076$

45 James Williams, 'The "clandestine university" is clandestine no more,' Prospect, 29 March 2018, https://www.prospectmagazine.co.uk/politics/the-clandestine-universityis-clandestine-no-more 
on whether neoliberalism is dead or alive risks becoming a quasi-theological question. Davies's book, exquisitely written and brimming with insights, offers a superb resource for grasping these connections. What we make of them is, as ever, up to us. 